\title{
Infected aortic aneurysm caused by Helicobacter cinaedi: case series and systematic review of the literature
}

\author{
Takahiro Matsuo $^{1 *}$ (D), Nobuyoshi Mori ${ }^{1}$, Atsushi Mizuno ${ }^{2,3,4}$, Aki Sakurai ${ }^{5}$, Fujimi Kawai ${ }^{6}$, Jay Starkey ${ }^{7}$, \\ Daisuke Ohkushi ${ }^{8}$, Kohei Abe ${ }^{9}$, Manabu Yamasaki ${ }^{9}$, Joji Ito $^{10}$, Kunihiko Yoshino ${ }^{9}$, Yumiko Mikami ${ }^{11}$, \\ Yuki Uehara ${ }^{1,11}$ and Keiichi Furukawa ${ }^{1,12}$
}

\begin{abstract}
Background: Helicobacter cinaedi is rarely identified as a cause of infected aneurysms; however, the number of reported cases has been increasing over several decades, especially in Japan. We report three cases of aortic aneurysm infected by $\mathrm{H}$. cinaedi that were successfully treated using meropenem plus surgical stent graft replacement or intravascular stenting. Furthermore, we performed a systematic review of the literature regarding aortic aneurysm infected by $\mathrm{H}$. cinaedi.

Case presentation: We present three rare cases of infected aneurysm caused by $\mathrm{H}$. cinaedi in adults. Blood and tissue cultures and 16S rRNA gene sequencing were used for diagnosis. Two patients underwent urgent surgical stent graft replacement, and the other patient underwent intravascular stenting. All three cases were treated successfully with intravenous meropenem for 4 to 6 weeks.

Conclusions: These cases suggest that although aneurysms infected by $H$. cinaedi are rare, clinicians should be aware of $\mathrm{H}$. cinaedi as a potential causative pathogen, even in immunocompetent patients. Prolonged incubation periods for blood cultures are necessary for the accurate detection of $\mathrm{H}$. cinaedi.
\end{abstract}

Keywords: Helicobacter cinaedi, Infected aneurysm, Japan, Case report

\section{Background}

Helicobacter cinaedi is a gram-negative spiral rod that was first discovered in the rectal culture from a man who had had sex with a man with proctitis [1]. $H$. cinaedi was thought to cause infection only in immunocompromised individuals; however, it has also been observed as a causative pathogen in immunocompetent patients [2-4]. H. cinaedi can cause bacteremia, skin and soft tissue infection, and arterial infection $[5,6]$.

\footnotetext{
${ }^{*}$ Correspondence: tmatsuo@luke.ac.jp

'Department of Infectious Diseases, St. Luke's International Hospital, 9-1, Akashi-cho, Chuo-ku, Tokyo, Japan

Full list of author information is available at the end of the article
}

Although infected (mycotic) aortic aneurysms are not common, they are difficult to treat and are associated with high morbidity and mortality. Mortality has been reported to be greater than $20 \%$, usually attributable to delays in diagnosis and subsequent complications, such as rupture and sepsis [7-9]. Common pathogens include Staphylococcus aureus, Streptococcus pneumoniae, and non-typhoidal Salmonella followed by other gramnegative organisms such as Escherichia coli, Klebsiella, and Pseudomonas spp. [10, 11]. Mycobacterium spp., Treponema palladium, and Chlamydophila spp. have also been reported as causative pathogens, although rarely $[12,13]$. 
Herein, we report three cases of aortic aneurysm infected by $H$. cinaed $i$ that were successfully treated using meropenem plus surgical stent graft replacement or intravascular stenting. Furthermore, we performed a systematic review of the literature regarding aortic aneurysm infected by $H$. cinaedi.

\section{Case series}

Case 1

A 77-year-old immunocompetent man with a past medical history of hypertension and dyslipidemia presented to our department with a fever up to $38^{\circ} \mathrm{C}$ and progressive left pleuritic chest pain for 2 weeks. On admission, the patient was not in acute distress and had a temperature of $37.6^{\circ} \mathrm{C}$, blood pressure of $143 / 76 \mathrm{mmHg}$, heart rate of $67 /$ $\mathrm{min}$, respiratory rate of $16 / \mathrm{min}$, and oxygen saturation of $95 \%$ on room air. The patient was noted to have coarse crackles over the left lower lobe of the lung and tenderness of the lower abdomen without any rebound or guarding. Laboratory data showed a mildly elevated white blood cell (WBC) count of $8100 / \mu \mathrm{L}$ and C-reactive protein (CRP) of $15.0 \mathrm{mg} / \mathrm{dL}$. Contrast-enhanced computed tomography (CT) chest-abdomen-pelvis examination demonstrated an aneurysm $(30 \times 42 \mathrm{~mm})$ of the aortic arch with suggestion of a Stanford B dissection involving the descending aorta on a background of abdominal vessel wall thickening (Fig. 1), increased thickness of bilateral common iliac arteries $(20 \times 25 \mathrm{~mm})$, and a $1 \mathrm{~cm}$ diameter lowdensity area in the spleen, compatible with infected vasculitis and splenic abscess.

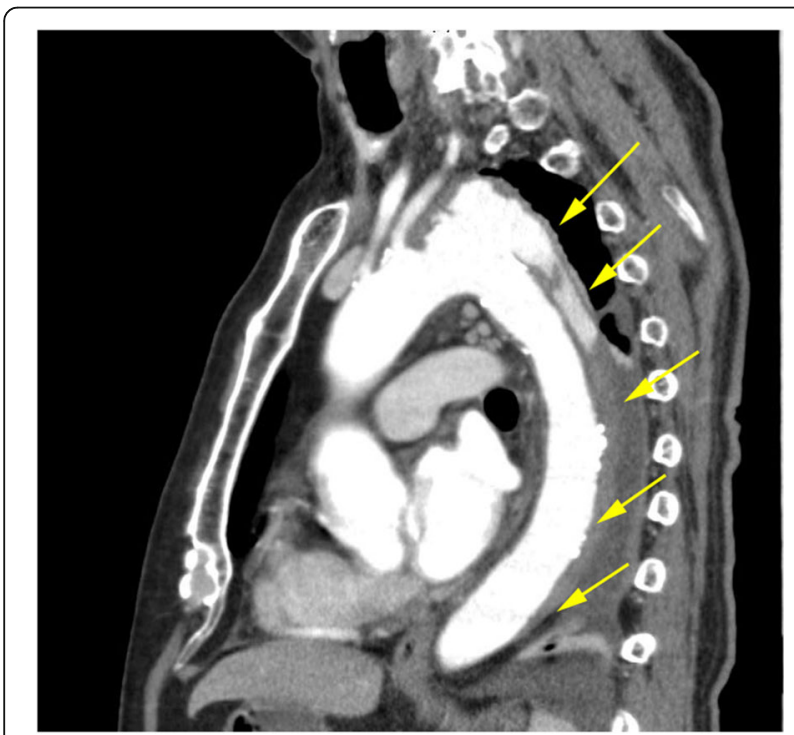

Fig. 1 Sagittal contrast-enhanced CT chest-abdomen-pelvis image demonstrates aorta wall thickening with pseudoaneurysm of the distal aortic arch and suggestion of Stanford type B dissection involving the descending aorta, with abnormal fluid extending to the level of the diaphragm
We initiated ceftriaxone $2 \mathrm{~g}$ intravenously (IV) every $24 \mathrm{~h}$, vancomycin IV $1 \mathrm{~g}$ every $12 \mathrm{~h}$, and minocycline IV $100 \mathrm{mg}$ every $12 \mathrm{~h}$. Due to the active infection, we opted for conservative management without immediate surgery. Despite empirical antimicrobial therapy, the patient had progressive lower abdominal pain on hospital day 4, and a follow-up CT scan demonstrated enlargement of the aortic arch aneurysm $(33 \times 49 \mathrm{~mm})$ and worsening aortic dissection. Therefore, total arch replacement was urgently performed on the same day. After surgery, the patient gradually improved. On hospital day 7, gramnegative spiral rods were cultured from blood samples obtained on admission (aerobic bottle, BacT/ALERT [bioMérieux, Inc., Durham, NC]). The empirical therapy was changed to meropenem $1 \mathrm{~g}$ IV every $6 \mathrm{~h}$. Final blood culture results revealed $H$. cinaedi. The minimum inhibitory concentrations (MICs) measured by Etest (bioMérieux) for this strain were as follows: meropenem $0.008 \mu \mathrm{g} / \mathrm{mL}$, penicillin $\mathrm{G}>32 \mu \mathrm{g} / \mathrm{mL}$, piperacillin/tazobactam $16 \mu \mathrm{g} / \mathrm{mL}$, cefotaxime $>32 \mu \mathrm{g} / \mathrm{mL}$, and levofloxacin $>32 \mu \mathrm{g} / \mathrm{mL}$. Tissue culture of the infected aneurysm was negative. We continued meropenem for 6 weeks after surgery. Follow-up CT revealed resolution of the vasculitis involving the common iliac arteries without evidence of infection. As there are limited data on oral antimicrobials against $H$. cinaedi, we consulted the data for $H$. pylori. As faropenem was found to have good antimicrobial action against $H$. pylori in vitro [14], the patient was discharged on hospital day 46 with oral faropenem. He continued oral faropenem for 1 year, and his general status was stable at a 4-year follow-up.

\section{Case 2}

An 85-year-old woman with a past medical history of polymyalgia rheumatica treated with oral prednisolone 5 mg every other day and hypertension presented to our hospital for fever up to $38^{\circ} \mathrm{C}$ and epigastric pain for 1 month that had not responded to a short course of oral cefcapene pivoxil. On admission, the patient was not in acute distress with a temperature of $36.9^{\circ} \mathrm{C}$, blood pressure of $158 / 48 \mathrm{mmHg}$, heart rate of $60 / \mathrm{min}$, respiratory rate of $18 / \mathrm{min}$, and oxygen saturation of $98 \%$ on room air. The patient was noted to have tenderness over the epigastric area but no rebound or guarding. Laboratory data showed an elevated $\mathrm{WBC}$ of $10,000 / \mu \mathrm{L}$, (neutrophils $75 \%$ ) and CRP of $5.27 \mathrm{mg} / \mathrm{dL}$. Contrast-enhanced CT chest-abdomen-pelvis demonstrated increased wall thickness of the descending aorta $(35 \times 32 \mathrm{~mm})$ and low attenuation surrounding the aorta, compatible with an infected aortic aneurysm.

We empirically initiated ceftriaxone $2 \mathrm{~g}$ IV every $24 \mathrm{~h}$. Her fever subsided and general status gradually improved. On hospital day 5, gram-negative spiral rods were cultured from blood samples obtained at admission 
(aerobic bottle, BacT/ALERT [bioMérieux]) (Fig. 2). Empirical therapy was changed to meropenem $1 \mathrm{~g}$ IV every $6 \mathrm{~h}$. On hospital day 7, 16S rRNA gene sequencing confirmed $H$. cinaedi. The MICs for this strain tested using the same method as for Case 1 were as follows: meropenem $0.008 \mu \mathrm{g} / \mathrm{mL}$, ampicillin $32 \mu \mathrm{g} / \mathrm{mL}$, cefotaxime > $32 \mu \mathrm{g} / \mathrm{mL}$, and levofloxacin $>32 \mu \mathrm{g} / \mathrm{mL}$. Follow-up CT on hospital day 17 revealed that the infected aneurysm had diminished $(33 \times 31 \mathrm{~mm})$. Subsequently, meropenem was switched to oral faropenem on hospital day 44 . Follow-up CT on hospital day 62 revealed enlargement of the infected aneurysm $(35 \times 42 \mathrm{~mm})$. Thereafter, urgent intravascular stenting was performed. After this procedure, the patient improved and was discharged on day 76 without further complications. The patient continued oral faropenem and was clinically stable without any sign of recurrence at the 6-year follow-up.

\section{Case 3}

A 72-year-old immunocompetent man with a past medical history of hypertension and benign prostate hypertrophy presented to the emergency room with difficult and painful urination for 10 days and lower abdominal pain for 3 days followed by fever up to $38^{\circ} \mathrm{C} 1$ day prior to admission. On admission, the patient was not in acute distress with a temperature of $37.8^{\circ} \mathrm{C}$, blood pressure of 120 / $70 \mathrm{mmHg}$, heart rate of $89 / \mathrm{min}$, respiratory rate of $18 /$ min, and oxygen saturation of $98 \%$ on room air. The patient was noted to have tenderness of the lower abdomen without any rebound or guarding. The prostate was elastic, soft, swollen, and tender. Laboratory data showed an elevated WBC of $9800 / \mu \mathrm{L}$, (neutrophils $78 \%$ ) and CRP of $18.9 \mathrm{mg} / \mathrm{dL}$. Contrast-enhanced CT chest-abdomen-pelvis demonstrated increased wall thickness of the descending aorta with a wild, multilobulated appearance with focal outpouching $(30 \times 31 \mathrm{~mm})$ and fat stranding surrounding

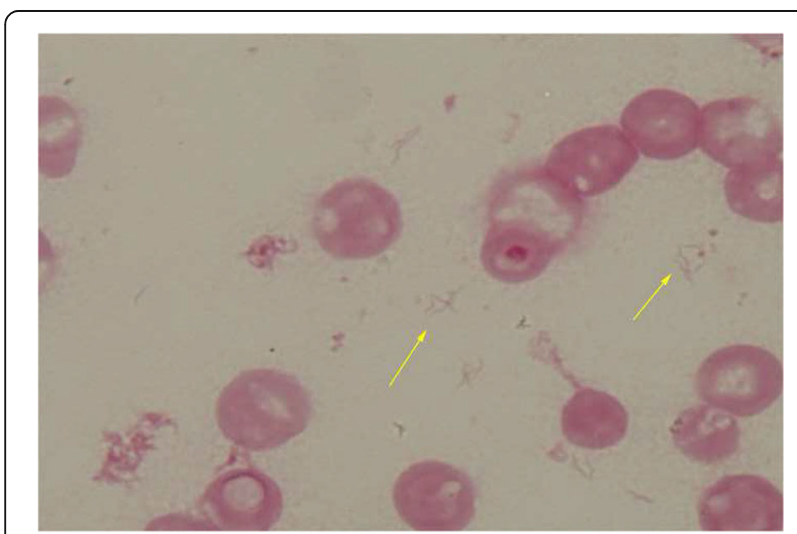

Fig. 2 Photomicrograph of Gram stain demonstrates gram-negative spiral rods, which grew on hospital day 5 from blood cultures taken at admission the aorta (Fig. 3), compatible with an infected aortic aneurysm.

We empirically started cefepime $1 \mathrm{~g}$ IV every $8 \mathrm{~h}$, vancomycin IV $1 \mathrm{~g}$ every $12 \mathrm{~h}$, and minocycline IV 100 mg every $12 \mathrm{~h}$. On hospital day 12, the patient complained of worsening of lower abdominal pain, and a follow-up CT scan revealed enlargement of the aneurysm $(36 \times 35 \mathrm{~mm})$. He underwent urgent abdominal aorta replacement on the same day. Tissue culture of the abdominal aneurysm was negative; however, $16 \mathrm{~S}$ rRNA gene sequencing identified $H$. cinaedi from the tissue. We could not perform the susceptibility testing because $H$. cinaedi isolates could not be obtained from blood and tissue culture. The empirical therapy was changed to meropenem $1 \mathrm{~g}$ IV every $6 \mathrm{~h}$. He was continued on meropenem for 4 weeks after surgical intervention and was discharged on hospital day 47 with oral faropenem. The patient continued oral faropenem for 3 years and was clinically stable without any sign of recurrence at the 5-year follow-up.

\section{Systematic review}

Two authors independently reviewed the titles and abstracts of database records, retrieved full texts for an eligibility assessment, and extracted data from these cases. A literature search was conducted in both the PubMed database (up to November 2019) using the keywords ((cinaedi) AND (“"Vascular Diseases"[Mesh]) OR (aneurysm"[TW]))) OR ((“Aneurysm, Infected"[Mesh]) AND ("Helicobacter"[Mesh] OR "Helicobacter Infections"[Mesh])) and the Embase database using the keywords (cinaedi OR 'helicobacter cinaedi'/exp) AND ('infected aneurysm'/exp. OR 'aortic aneurysm'/exp. OR 'aneurysm') (Fig. 4). Knowing that there were several reports in Japanese papers, we have included those published only in Japanese in order to further understand the clinical

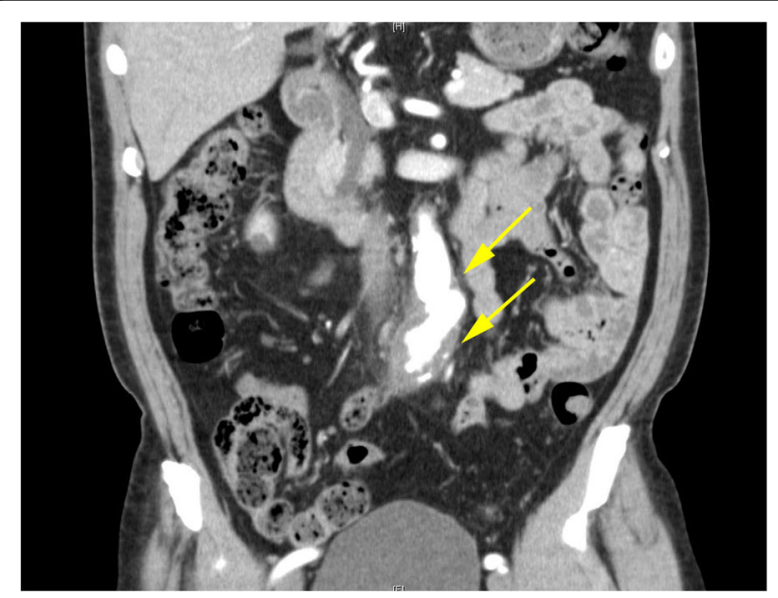

Fig. 3 Coronal contrast-enhanced CT abdomen image demonstrates irregular wall thickening of the descending aorta having a wild, multilobulated appearance with surrounding soft tissue stranding 


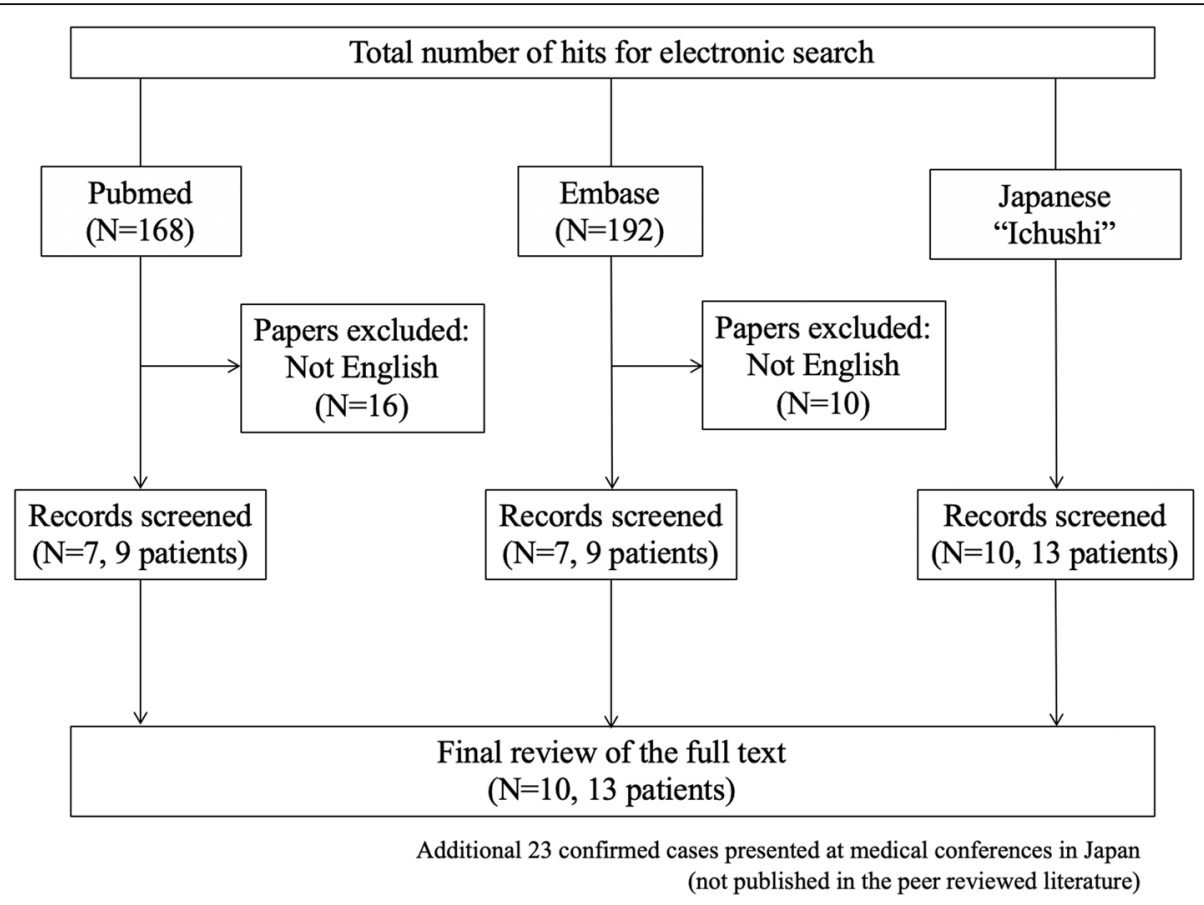

Fig. 4 Flow chart depicts the systematic review process of this study

characteristics of the disease by presenting more confirmed cases. In order to search for articles in Japanese, we used Ichushi, a major Japanese database, using the keywords ((cinaedi/AL)) or ("Helicobacter cinaedi"/TH)) and (((aneurysm [Japanese]/TH or aneurysm/AL)) or ((Vascular diseases [Japanese]/TH or Vascular diseases/AL)) or ((Artery [Japanese]/TH or Artery [Japanese]/AL))).

We found ten papers describing thirteen cases of infected aneurysms due to $H$. cinaedi, all from Japan [6, 15-23]. Additionally, there were twenty-three confirmed cases presented in Japan at medical conferences, though not published in the peer reviewed literature. However, for these cases detailed patient information was not available. The clinical characteristics of the thirteen published cases, including our three cases, are shown in Table 1. Among them, the most common site of infection was the abdominal aorta (at least nine patients). Only two patient received oral corticosteroids; the others were immunocompetent. Regarding management, except for two cases with conservative management, the remaining eleven patients underwent in situ grafting, extra-anatomical bypass, or intravascular stent. Except one patient with fungal infection, all patients were successfully treated without further complications.

\section{Discussion and conclusions}

This is the first systematic review of infected aortic aneurysms caused by $H$. cinaedi. The mechanisms underlying infected aortic aneurysms remain unknown.
However, four main mechanisms have been hypothesized that result in infection of the arterial wall: 1) the development of infected aneurysms secondary to septic microemboli of the vasa vasorum, 2) extension from a contiguous infected focus, 3) hematogenous seeding of the intima during bacteremia originating from a distant infection, and 4) trauma to the arterial wall with contamination [24]. Recently, Araoka et al. reported that bacterial translocation from the intestinal tract could be a route that leads to $H$. cinaedi bacteremia [25]. The promotion of atherosclerosis by $H$. cinaedi has also been reported [26, 27]. In our three cases, none had evidence of infection with $H$. cinaedi at distal sites, extension from a contiguous infected focus, or a history of trauma; therefore, the development of infected aneurysms secondary to septic microemboli of the vasa vasorum or bacterial translocation from the intestinal tract were considered the most likely mechanisms.

There is a lack of data on susceptibility testing, and standard breakpoints of antimicrobial agents for $H$. cinaedi have not been defined. Previous studies reported that susceptibility testing for $H$. cinaedi isolates has been conducted using the agar dilution method [28, 29]. Low MIC values were generally reported for $H$. cinaedi strains for carbapenems, aminoglycosides, and tetracycline $\left(\mathrm{MIC}_{90} \leq 1 \mu \mathrm{g} / \mathrm{mL}\right)[5,30]$, moderate MIC values for ampicillin $\left(\mathrm{MIC}_{90}=16 \mu \mathrm{g} / \mathrm{mL}\right)$, cefepime $\left(\mathrm{MIC}_{90}=8 \mu \mathrm{g} /\right.$ $\mathrm{mL}$ ), and ceftriaxone $\left(\mathrm{MIC}_{90}=8 \mu \mathrm{g} / \mathrm{mL}\right)$ [5], and high $\mathrm{MIC}$ values for erythromycin $\left(\mathrm{MIC}_{90}>64 \mu \mathrm{g} / \mathrm{mL}\right)$ [31]. 
Table 1 Clinical characteristics of cases of aortic aneurysm infected with Helicobacter cinaedi

\begin{tabular}{|c|c|c|c|c|c|c|c|c|c|c|}
\hline No & $\begin{array}{l}\text { Case } \\
\text { reference }\end{array}$ & $\begin{array}{l}\text { Age } \\
\text { (years) }\end{array}$ & Sex & $\begin{array}{l}\text { Published } \\
\text { year }\end{array}$ & $\begin{array}{l}\text { Underlying } \\
\text { diseases }\end{array}$ & $\begin{array}{l}\text { Chief } \\
\text { complaint }\end{array}$ & $\begin{array}{l}\text { Site of } \\
\text { infection }\end{array}$ & Management & Antimicrobial used & Outcome \\
\hline 1 & R. Kakuta & 64 & Male & 2014 & Hypertension & $\begin{array}{l}\text { Fever, back } \\
\text { pain }\end{array}$ & $\begin{array}{l}\text { Infrarenal } \\
\text { abdominal, L } \\
\text { common iliac, } \\
R \text { internal } \\
\text { iliac, and L } \\
\text { femoral artery }\end{array}$ & $\begin{array}{l}\text { In situ } \\
\text { grafting }\end{array}$ & $\begin{array}{l}\text { Sulbactam/ampicillin } 3 \\
\text { g/day and minocycline } \\
100 \text { mg/day for } 25 \text { days } \\
\text { followed by oral } \\
\text { amoxicillin } 1500 \mathrm{mg} / \\
\text { day and minocycline } \\
200 \text { mg/day }\end{array}$ & $\begin{array}{l}\text { Complete } \\
\text { symptom } \\
\text { resolution }\end{array}$ \\
\hline 2 & R. Kakuta & 59 & Male & 2014 & None & $\begin{array}{l}\text { Fever, } \\
\text { abdominal } \\
\text { pain }\end{array}$ & $\begin{array}{l}\text { Infrarenal } \\
\text { abdominal } \\
\text { aorta }\end{array}$ & $\begin{array}{l}\text { In situ } \\
\text { grafting }\end{array}$ & $\begin{array}{l}\text { Piperacillin/tazobactam } \\
4.5 \mathrm{~g} / \text { day for } 28 \text { days } \\
\text { followed by oral } \\
\text { amoxicillin } 1500 \mathrm{mg} / \\
\text { day and minocycline } \\
200 \mathrm{mg} / \text { day until } \\
\text { follow-up visit }\end{array}$ & $\begin{array}{l}\text { Complete } \\
\text { symptom } \\
\text { resolution }\end{array}$ \\
\hline 3 & R. Kakuta & 62 & Male & 2014 & $\begin{array}{l}\text { History of } \\
\text { myocardial } \\
\text { infarction }\end{array}$ & $\begin{array}{l}\text { Low back } \\
\text { pain }\end{array}$ & $\begin{array}{l}\text { Infrarenal } \\
\text { abdominal } \\
\text { aorta }\end{array}$ & $\begin{array}{l}\text { In situ } \\
\text { grafting }\end{array}$ & $\begin{array}{l}\text { Doripenem, } 1.5 \mathrm{~g} / \text { day } \\
\text { for } 28 \text { days followed by } \\
\text { oral amoxicillin } 1500 \\
\text { mg/day and } \\
\text { minocycline } 200 \mathrm{mg} / \mathrm{d} \text {, } \\
\text { until follow-up visit }\end{array}$ & $\begin{array}{l}\text { Complete } \\
\text { symptom } \\
\text { resolution }\end{array}$ \\
\hline 4 & K. Niimi & 60 & Female & 2014 & $\begin{array}{l}\text { Rheumatic } \\
\text { arthritis on } \\
\text { prednisolone, } \\
\text { end-stage kid- } \\
\text { ney disease } \\
\text { on } \\
\text { hemodialysis, } \\
\text { MDR-TB }\end{array}$ & $\begin{array}{l}\text { Fever, left } \\
\text { inguinal } \\
\text { pain }\end{array}$ & $\begin{array}{l}L \text { femoral } \\
\text { artery }\end{array}$ & $\begin{array}{l}\text { Resection of } \\
\text { the aneurysm } \\
\text { and } \\
\text { debridement }\end{array}$ & $\begin{array}{l}\text { Ceftazidime } 1 \mathrm{~g} / \text { day for } \\
5 \text { days followed by } \\
\text { imipenem-cilastatin } \\
500 \mathrm{mg} / \text { day for } 10 \text { days, } \\
\text { ampicillin/sulbactam } 3 \\
\text { g/day for } 2 \text { weeks, and } \\
\text { oral ampicillin/sulbac- } \\
\text { tam for } 1 \text { month }\end{array}$ & $\begin{array}{l}\text { Complete } \\
\text { symptom } \\
\text { resolution }\end{array}$ \\
\hline 5 & T. Seto & 39 & Male & 2014 & None & $\begin{array}{l}\text { Fever, } \\
\text { chest pain }\end{array}$ & $\begin{array}{l}\text { Right } \\
\text { coronary } \\
\text { artery } \\
\text { (pericoronary } \\
\text { pseudotumor) }\end{array}$ & Conservative & Ceftriaxone for 2 weeks & $\begin{array}{l}\text { Complete } \\
\text { symptom } \\
\text { resolution }\end{array}$ \\
\hline 6 & $\begin{array}{l}\text { S. } \\
\text { Unosawa }\end{array}$ & 79 & Male & 2015 & Hypertension & $\begin{array}{l}\text { Back pain, } \\
\text { left lower } \\
\text { quadrant } \\
\text { pain }\end{array}$ & $\begin{array}{l}\text { Infrarenal } \\
\text { abdominal } \\
\text { aorta }\end{array}$ & $\begin{array}{l}\text { In situ } \\
\text { grafting with } \\
\text { an omental } \\
\text { wrapping }\end{array}$ & $\begin{array}{l}\text { Ceftriaxone } 2 \mathrm{~g} / \text { day and } \\
\text { gentamicin } 120 \mathrm{mg} / \text { day, } \\
\text { followed by sultamicillin } \\
1250 \mathrm{mg} / \text { day }\end{array}$ & $\begin{array}{l}\text { Complete } \\
\text { symptom } \\
\text { resolution }\end{array}$ \\
\hline 7 & K. Nishida & 64 & Male & 2015 & None & $\begin{array}{l}\text { Low back } \\
\text { pain }\end{array}$ & $\begin{array}{l}\text { Infrarenal } \\
\text { abdominal } \\
\text { aorta, L } \\
\text { common iliac } \\
\text { artery }\end{array}$ & $\begin{array}{l}\text { In situ } \\
\text { grafting }\end{array}$ & $\begin{array}{l}\text { Meropenem and } \\
\text { vancomycin for } 8 \text { weeks }\end{array}$ & $\begin{array}{l}\text { Complete } \\
\text { symptom } \\
\text { resolution }\end{array}$ \\
\hline 8 & $\begin{array}{l}\text { M. } \\
\text { Akiyama }\end{array}$ & 49 & Female & 2016 & $\begin{array}{l}\text { History of } \\
\text { myocardial } \\
\text { infarction }\end{array}$ & $\begin{array}{l}\text { Fever, back } \\
\text { pain }\end{array}$ & $\begin{array}{l}\text { Abdominal } \\
\text { aorta, bilateral } \\
\text { common iliac } \\
\text { artery }\end{array}$ & $\begin{array}{l}\text { In situ } \\
\text { grafting with } \\
\text { an omental } \\
\text { wrapping }\end{array}$ & $\begin{array}{l}\text { Piperacillin/tazobactam } \\
\text { followed by oral } \\
\text { amoxicillin, } 1500 \text { mg/ } \\
\text { day, and minocycline } \\
200 \mathrm{mg} / \text { day for } 3 \\
\text { months }\end{array}$ & $\begin{array}{l}\text { Complete } \\
\text { symptom } \\
\text { resolution }\end{array}$ \\
\hline 9 & J. Inagaki & 80 & Male & 2017 & None & Fatigue & $\begin{array}{l}\text { Infrarenal } \\
\text { abdominal } \\
\text { aorta, bilateral } \\
\text { common iliac } \\
\text { artery }\end{array}$ & $\begin{array}{l}\text { Extra- } \\
\text { anatomical } \\
\text { bypass }\end{array}$ & $\begin{array}{l}\text { Meropenem and } \\
\text { levofloxacin (dose not } \\
\text { available) for } 6 \text { weeks } \\
\text { followed by } \\
\text { minocycline and } \\
\text { rifampicin for more } \\
\text { than } 18 \text { months }\end{array}$ & $\begin{array}{l}\text { Complete } \\
\text { symptom } \\
\text { resolution } \\
\text { with } \\
\text { continued } \\
\text { antimicrobials }\end{array}$ \\
\hline 10 & $\begin{array}{l}\text { K. } \\
\text { Kushimoto }\end{array}$ & 68 & Male & 2017 & $\begin{array}{l}\text { Hypertension, } \\
\text { hyperuricemia }\end{array}$ & $\begin{array}{l}\text { Fever, } \\
\text { chest and } \\
\text { back pain }\end{array}$ & $\begin{array}{l}\text { Distal aortic } \\
\text { arch, thoracic } \\
\text { aorta }\end{array}$ & $\begin{array}{l}\text { In situ } \\
\text { grafting with } \\
\text { an omental } \\
\text { wrapping }\end{array}$ & $\begin{array}{l}\text { Levofloxacin } 250 \mathrm{mg} / \\
\text { day for } 19 \text { days } \\
\text { followed by } \\
\text { minocycline } 200 \mathrm{mg} / \\
\text { day }\end{array}$ & $\begin{array}{l}\text { Complete } \\
\text { symptom } \\
\text { resolution } \\
\text { with } \\
\text { continued } \\
\text { antimicrobials }\end{array}$ \\
\hline 11 & Y. Kanno & 73 & Male & 2018 & History of & Back pain & Abdominal & Conservative & Meropenem 3 g/day & Complete \\
\hline
\end{tabular}


Table 1 Clinical characteristics of cases of aortic aneurysm infected with Helicobacter cinaedi (Continued)

\begin{tabular}{|c|c|c|c|c|c|c|c|c|c|c|}
\hline No & $\begin{array}{l}\text { Case } \\
\text { reference }\end{array}$ & $\begin{array}{l}\text { Age } \\
\text { (years) }\end{array}$ & Sex & $\begin{array}{l}\text { Published } \\
\text { year }\end{array}$ & $\begin{array}{l}\text { Underlying } \\
\text { diseases }\end{array}$ & $\begin{array}{l}\text { Chief } \\
\text { complaint }\end{array}$ & $\begin{array}{l}\text { Site of } \\
\text { infection }\end{array}$ & Management & Antimicrobial used & Outcome \\
\hline & & & & & $\begin{array}{l}\text { abdominal } \\
\text { aortic } \\
\text { aneurysm, } \\
\text { colon polyp }\end{array}$ & & aorta & $\begin{array}{l}\text { first, followed } \\
\text { by in situ } \\
\text { grafting } 3 \\
\text { months later }\end{array}$ & $\begin{array}{l}\text { and vancomycin } 1 \mathrm{~g} / \\
\text { day for } 7 \text { days followed } \\
\text { by levofloxacin } 500 \mathrm{mg} / \\
\text { day for } 5 \text { days, and oral } \\
\text { sultamicillin } 1200 \mathrm{mg} / \\
\text { day for } 3 \text { months } \\
\text { (relapsed) ampicillin/ } \\
\text { sulbactam } 6 \mathrm{~g} / \text { day for } \\
12 \text { days followed by } \\
\text { oral sultamicillin } 1200 \\
\text { mg/day (duration not } \\
\text { available) }\end{array}$ & $\begin{array}{l}\text { symptom } \\
\text { resolution }\end{array}$ \\
\hline 12 & Y. Kanno & 72 & Male & 2018 & None & Fever & Thoracic aorta & $\begin{array}{l}\text { In situ } \\
\text { grafting }\end{array}$ & $\begin{array}{l}\text { Meropenem } 3 \mathrm{~g} / \text { day } \\
\text { and vancomycin } 1 \mathrm{~g} / \\
\text { day followed by } \\
\text { ampicillin/sulbactam } 6 \\
\text { g/day }\end{array}$ & $\begin{array}{l}\text { Deceased } \\
\text { (fungal } \\
\text { infection) }\end{array}$ \\
\hline 13 & S. Nakao & 65 & Male & 2018 & None & $\begin{array}{l}\text { Fever and } \\
\text { right neck } \\
\text { pain }\end{array}$ & $\begin{array}{l}\text { R common } \\
\text { carotid artery }\end{array}$ & Conservative & $\begin{array}{l}\text { (1st) Meropenem } 6 \mathrm{~g} / \\
\text { day followed by } \\
\text { ceftriaxone } 4 \mathrm{~g} / \text { day for } \\
2 \text { weeks and oral } \\
\text { minocycline } 200 \mathrm{mg} / \\
\text { day for } 2 \text { weeks } \\
\text { (2nd) Ceftriaxone } 4 \mathrm{~g} / \\
\text { day for } 2 \text { weeks } \\
\text { followed by oral } \\
\text { ampicillin } 1.5 \mathrm{~g} / \text { day and } \\
\text { doxycycline } 400 \mathrm{mg} / \text { day } \\
\text { for } 6 \text { weeks }\end{array}$ & $\begin{array}{l}\text { Complete } \\
\text { symptom } \\
\text { resolution }\end{array}$ \\
\hline 14 & T. Matsuo & 77 & Male & 2020 & Hypertension & $\begin{array}{l}\text { Fever and } \\
\text { left chest } \\
\text { pain }\end{array}$ & $\begin{array}{l}\text { Aortic arch } \\
\text { and bilateral } \\
\text { common iliac } \\
\text { artery }\end{array}$ & $\begin{array}{l}\text { In situ } \\
\text { grafting }\end{array}$ & $\begin{array}{l}\text { Meropenem followed } \\
\text { by faropenem } 1200 \\
\text { mg/day for } 1 \text { year }\end{array}$ & $\begin{array}{l}\text { Complete } \\
\text { symptom } \\
\text { resolution }\end{array}$ \\
\hline 15 & T. Matsuo & 85 & Female & 2020 & $\begin{array}{l}\text { Polymyalgia } \\
\text { rheumatica } \\
\text { and } \\
\text { hypertension }\end{array}$ & $\begin{array}{l}\text { Epigastric } \\
\text { pain }\end{array}$ & $\begin{array}{l}\text { Descending } \\
\text { aorta }\end{array}$ & $\begin{array}{l}\text { Intravascular } \\
\text { stent }\end{array}$ & $\begin{array}{l}\text { Meropenem followed } \\
\text { by faropenem } 1200 \\
\text { mg/day }\end{array}$ & $\begin{array}{l}\text { Complete } \\
\text { symptom } \\
\text { resolution } \\
\text { with } \\
\text { continued } \\
\text { antimicrobials }\end{array}$ \\
\hline 16 & T. Matsuo & 72 & Male & 2020 & $\begin{array}{l}\text { Hypertension } \\
\text { and benign } \\
\text { prostate } \\
\text { hypertrophy }\end{array}$ & $\begin{array}{l}\text { Fever and } \\
\text { lower } \\
\text { abdominal } \\
\text { pain }\end{array}$ & $\begin{array}{l}\text { Bilateral } \\
\text { common iliac } \\
\text { artery }\end{array}$ & $\begin{array}{l}\text { In situ } \\
\text { grafting }\end{array}$ & $\begin{array}{l}\text { Meropenem followed } \\
\text { by faropenem } 1200 \\
\text { mg/day for } 3 \text { years }\end{array}$ & $\begin{array}{l}\text { Complete } \\
\text { symptom } \\
\text { resolution }\end{array}$ \\
\hline
\end{tabular}

L Left, $R$ Right, MDR-TB Multidrug-resistant tuberculosis

Prior to 2000, low MICs of ciprofloxacin and macrolides were reported for $H$. cinaedi; however, the majority of $H$. cinaedi isolates have gained resistance since the early 2000 s because of the increased use of these antimicrobials [30]. As the agar dilution method is not available in all institutes, the Etest could be an alternative method; however, it can be inaccurate because of the unclear edges around the growth inhibition zone [5]. Although there are no guidelines for recommended antimicrobial treatment, there has been varied used of beta-lactams such as penicillin, cephalosporin, and carbapenem [2, 32]. Monotherapy versus combination therapy has not been fully investigated. Further studies exploring the antimicrobial susceptibility profiles are warranted.
Except for one case, all of the reviewed cases underwent open repair (OR). OR is considered the gold standard with weak evidence supporting its superiority compared with endovascular aortic repair (EVAR). The optimal treatment of infected aneurysms remains unknown, although an increasing number of trials have reported EVAR as an alternative treatment for infected aortic aneurysms, with improved short-term survival compared with OR without the associated higher incidence of serious infection-related complications or reoperations [33]. In contrast, Luo et al. reported that persistent infection after EVAR does occur and is often fatal without surgical treatment [34]. The choice between OR or EVAR should be weighed against the risks and benefits for each patient. 
The optimal duration of antimicrobial therapy for $H$. cinaedi infection also remains unknown. In addition to IV antimicrobials for at least 6 weeks after surgery, some experts recommend that patients continue oral antimicrobials after discharge for at least 6 months whereas others recommend lifelong therapy [8]. All of our patients continued antimicrobials for at least for 1 year.

Regarding the incidence and prevalence of $H$. cinaedi, all published reports of infected aneurysms caused by $H$. cinaedi are from Japan. The number of reports of $H$. cinaedi overall infection, including bacteremia and skin and soft tissue infection, has been increasing over the last 10 years, especially in Japan. It is thought that there are three main reasons for this. First, as $H$. cinaedi is becoming increasingly recognized in Japan, many institutions are extending the incubation period for blood cultures when clinicians suspect $H$. cinaedi infection. $H$. cinaedi usually grows slowly, and one clinical research study from Japan revealed that approximately 50\% of $H$. cinaedi bacteremia would probably have been overlooked had the duration of monitored blood cultures been limited to 5 days [35]. After this report, many institutes extended the incubation period. Another hypothesis is that $H$. cinaedi may be related to Japanese-specific cultural behaviors such as eating raw fish as sushi and sashimi followed by colonization of $H$. cinaedi in the intestine. However, this is perhaps less likely given the increasing worldwide popularity of Japanese cuisine. Finally, some institutions have changed blood culture products, moving from BacT/ALERT to BACTEC (BD Diagnostics, Sparks, MD), and this could also be contributing to the increased detection of $H$. cinaedi [36]. New BacT/ALERT plus bottles that modify the antimicrobialabsorbing materials in the blood culture media could also have contributed to the improved detection [37, 38]. However, the true reason why $H$. cinaedi infections are increasing in Japan is as yet unknown. As these detections were made using the blood culture system described above for extended cultures and 16S rRNA gene sequencing in tissues, the sensitivity and specificity of the techniques for diagnosis and detection should be analyzed in the future. Furthermore, studies on the true mechanisms of $H$. cinaedi infections and its incidence and prevalence are warranted.

In summary, aortic aneurysms infected with $H$. cinaedi are rare and occur in immunocompetent as well as immunocompromised individuals. Clinicians should suspect $H$. cinaedi as a possible causative pathogen in patients with infected aortic aneurysms and extend the incubation period for blood cultures. The optimal choice of antimicrobials for $H$. cinaedi, the duration of therapy for infected aneurysms, and the optimal intervention regarding OR versus EVAR should be investigated in further studies.

\begin{abstract}
Abbreviations
H. cinaedi: Helicobacter cinaedi; WBC: White blood cell; CRP: C-reactive protein; CT: Contrast whole trunk computed tomography; IV: Intravenously; MIC: Minimum inhibitory concentration; OR: Open repair; EVAR: Endovascular aortic repair; C. trachomatis: Chlamydia trachomatis
\end{abstract}

\section{Acknowledgments}

We wish to thank Dr. Kiyofumi Okusu, Department of Microbiology, Tokyo Medical University, for performing the 165 rRNA sequencing and Dr. Emiko Hayashihara, National Institute of Infectious Diseases, for the susceptibility testing identification.

\section{Authors' contributions \\ The manuscript was seen and approved by all the authors and is not under consideration elsewhere. All the authors contributed to the work in this report. TM collected clinical data and wrote the initial draft of the manuscript. TM and FK performed the systematic review of the literature. $\mathrm{NM}, \mathrm{AM}, \mathrm{AS}, \mathrm{JS}, \mathrm{DO}, \mathrm{KA}, \mathrm{MY}, \mathrm{Jl}, \mathrm{KY}, \mathrm{YM}, \mathrm{YU}$, and KF supervised and edited the manuscript. The author(s) read and approved the final manuscript.}

\section{Funding}

There were no sources of funding used in the conception, composition, editing, or submission of this manuscript.

\section{Availability of data and materials \\ Not applicable.}

Ethics approval and consent to participate Not applicable.

\section{Consent for publication}

Written informed consent was obtained from the patients in this case report. A copy of written consent is available for the journal.

\section{Competing interests}

The authors declare that they have no competing interests.

\section{Author details}

'Department of Infectious Diseases, St. Luke's International Hospital, 9-1, Akashi-cho, Chuo-ku, Tokyo, Japan. ${ }^{2}$ Department of Cardiology, St. Luke's International Hospital, Tokyo, Japan. ${ }^{3}$ Penn Medicine Nudge Unit, University of Pennsylvania, Philadelphia, USA. ${ }^{4}$ Leonard Davis Institute for Health Economics, University of Pennsylvania, Philadelphia, USA. ${ }^{5}$ Department of Infectious Diseases, Fujita Health University, Aichi, Japan. ${ }^{6}$ St. Luke's International University Library, Tokyo, Japan. ${ }^{7}$ Department of Diagnostic Radiology, Division of Neuroradiology, Oregon Health \& Science University, Portland, OR, USA. ${ }^{8}$ Department of Infectious Diseases, Cancer Institute Hospital, Japanese Foundation for Cancer Research, Tokyo, Japan.

${ }^{9}$ Department of Cardiovascular Surgery, St. Luke's International Hospital, Tokyo, Japan. ${ }^{10}$ Department of Cardiovascular Surgery, Tokyo Bay Urayasu Ichikawa Medical Center, Chiba, Japan. ${ }^{11}$ Department of Clinical Laboratory, St. Luke's International Hospital, Tokyo, Japan. ${ }^{12}$ Department of Infectious Diseases, Asahi General Hospital, Chiba, Japan.

Received: 2 July 2020 Accepted: 3 November 2020

Published online: 17 November 2020

\section{References}

1. Fennel $C L$, Totten PA, Quinn TC, Patton DL, Holmes KK, Stamm WE. Characterization of campylobacter-like organisms isolated from homosexual men. J Infect Dis. 1984;149:58-66.

2. Kitamura T, Kawamura Y, Ohkusu K, Masaki T, Iwashita H, Sawa T, et al. Helicobacter cinaedi cellulitis and bacteremia in immunocompetent hosts after orthopedic surgery. J Clin Microbiol. 2007;45:31-8.

3. Murata S, Suzuki H, Sakamoto S, Miki T, Rimbara E, Shibayama K, et al. Helicobacter cinaedi-associated vertebral osteomyelitis in an immunocompetent patient. Intern Med. 2015;54:3221-4.

4. Shimizu Y, Gomi H, Ishioka H, Isono M. Refractory to treat Helicobacter cinaedi bacteremia with bilateral lower extremities cellulitis in an immunocompetent patient. IDCases. 2016;5:9-11. 
5. Kawamura Y, Tomida J, Morita Y, Fujii S, Okamoto T, Akaike T. Clinical and bacteriological characteristics of Helicobacter cinaedi infection. J Infect Chemother. 2014;20:517-26.

6. Nakao S, Hagiya H, Kimura K, Mitsui T, Oyama A, Hongyo K, et al. Helicobacter cinaedi-associated carotid arteritis. Acta Med Okayama. 2018;72: 189-92.

7. Oderich GS, Panneton JM, Bower TC, Cherry KJ, Rowland CM, Noel AA, et al. Infected aortic aneurysms: aggressive presentation, complicated early outcome, but durable results. J Vasc Surg. 2001;34:900-8.

8. Hsu R-B, Tsay Y-G, Wang S-S, Chu S-H. Surgical treatment for primary infected aneurysm of the descending thoracic aorta, abdominal aorta, and iliac arteries. J Vasc Surg. 2002;36:746-50.

9. Moneta GL, Taylor LM, Yeager RA, Edwards JM, Nicoloff AD, McConnell DB, et al. Surgical treatment of infected aortic aneurysm. Am J Surg. 1998;175: 396-9.

10. Marques da Silva R, Caugant DA, ERK E, Aas JA, Lingaas PS, Geiran O, et al. Bacterial diversity in aortic aneurysms determined by $16 \mathrm{~S}$ ribosomal RNA gene analysis. J Vasc Surg. 2006;44:1055-60.

11. Brossier J, Lesprit P, Marzelle J, Allaire E, Becquemin J-P, Desgranges P. New bacteriological patterns in primary infected aorto-iliac aneurysms: a singleCentre experience. Eur J Vasc Endovasc Surg. 2010;40:582-8.

12. Canaud L, Marzelle J, Bassinet L, Carrié A-S, Desgranges P, Becquemin J-P. Tuberculous aneurysms of the abdominal aorta. J Vasc Surg. 2008;48:1012-6.

13. Cruz RP, Marrone LCP, Marrone ACH. Chronic syphilitic aortic aneurysm complicated with chronic aortic dissection. Am J Surg. 2010;200:e64-6.

14. Ogura K, Mitsuno Y, Maeda S, Hirata Y, Yanai A, Shibata W, et al. Efficacy and safety of faropenem in eradication therapy of Helicobacter pylori. Helicobacter. 2007;12:618-22.

15. Kakuta R, Yano H, Kanamori H, Shimizu T, Gu Y, Hatta M, et al. Helicobacter cinaedi infection of abdominal aortic aneurysm, Japan. Emerg Infect Dis. 2014;20:1942-5.

16. Unosawa $\mathrm{S}$, Niino T. An infected abdominal aortic aneurysm caused by Helicobacter cinaedi. Ann Vasc Dis. 2015;8:318-20.

17. Nishida K, Iwasawa T, Tamura A, Lefor AT. Infected abdominal aortic aneurysm with Helicobacter cinaedi. Case Rep Surg. 2016;2016:1396568. https://doi.org/10.1155/2016/1396568.

18. Akiyama M, Hayatsu Y, Sakatsume K, Fujiwara H, Shimizu T, Akamatsu D, et al. Graft placement with an omental flap for ruptured infective common iliac aneurysm in a patient with a continuous flow left ventricular assist device: alternative surgical approach avoiding driveline injury and pathogen identification by 165 ribosomal DNA. J Artif Organs. 2016;19:383-6.

19. Niimi K, Ichihara T, Sasaki M. A case of mycotic deep femoral artery aneurysm due to Helicobacter cinaedi bacteremia. J Jpn Coll Angiol. 2014;54: 51-5 (Japanese).

20. Seto T, Takano T, Ichimura H. Pericoronary pseudotumor caused by Helicobacter cinaedi. Int Heart J. 2014;55:463-5.

21. Inagaki M, Tokui T, Maze Y. Six cases of infected abdominal aortic aneurysm. Jpn J Cardiovasc Surg. 2017;46:17-20 Japanese.

22. Kushimoto K, Yonekura R, Umesue M. Infected thoracic aortic aneurysm caused by Helicobacter cinaedi. Ann Vasc Dis. 2017;10(2):139-42.

23. Kanno Y, Shimizu R, Takei Y. Helicobacter cinaedi from infected aortic aneurysm, 2 cases reports. Jpn J Vasc Surg. 2018;27:273-6 Japanese.

24. Bennett JE, Dolin R, Blaser MJ. Mandell, Douglas, and Bennett's principles and practice of infectious diseases. 8th ed. Elsevier Saunders: Philadelpha; 2014.

25. Araoka H, Baba M, Okada C, Kimura M, Sato T, Yatomi Y, et al. First evidence of bacterial translocation from the intestinal tract as a route of Helicobacter cinaedi bacteremia. Helicobacter. 2018;23:e12458. https://doi.org/10.1111/ hel. 12458

26. Khan S, Okamoto T, Enomoto K, Sakashita N, Oyama K, Fujii S, et al. Potential association of Helicobacter cinaedi with atrial arrhythmias and atherosclerosis. Microbiol Immunol. 2012;56:145-54.

27. Khan S, Rahman HNA, Okamoto T, Matsunaga T, Fujiwara Y, Sawa T, et al. Promotion of atherosclerosis by Helicobacter cinaedi infection that involves macrophage-driven proinflammatory responses. Sci Rep. 2015:4:4680.

28. Kiehlbauch JA, Brenner DJ, Cameron DN, Steigerwalt AG, Makowski JM, Baker CN, et al. Genotypic and phenotypic characterization of Helicobacter cinaedi and Helicobacter fennelliae strains isolated from humans and animals. J Clin Microbiol. 1995;33:2940-7.

29. Tee W, Street AC, Spelman D, Munckhof W, Mijch A. Helicobacter cinaedi bacteraemia: varied clinical manifestations in three homosexual males. Scand J Infect Dis. 1996;28:199-203.
30. Rimbara E, Mori S, Matsui M, Suzuki S, Wachino Jl, Kawamura Y, et al. Molecular epidemiologic analysis and antimicrobial resistance of Helicobacter cinaedi isolated from seven hospitals in Japan. J Clin Microbiol. 2012:50:2553-60.

31. Kuijper EJ, Stevens S, Imamura T, De Wever B, Claas ECJ. Genotypic identification of erythromycin-resistant Campylobacter isolates as Helicobacter species and analysis of resistance mechanism. J Clin Microbiol. 2003:41:3732-6.

32. Matsumoto T, Goto M, Murakami H, Tanaka T, Nishiyama H, Ono E, et al. Multicenter study to evaluate bloodstream infection by Helicobacter cinaedi in Japan. J Clin Microbiol. 2007:45:2853-7.

33. Sörelius K, Wanhainen A, Furebring M, Björck M, Gillgren P, Mani K, et al. Nationwide study of the treatment of mycotic abdominal aortic aneurysms comparing open and endovascular repair. Circulation. 2016;134:1822-32.

34. Luo C-M, Chan C-Y, Chen Y-S, Wang S-S, Chi N-H, Wu I-H. Long-term outcome of endovascular treatment for mycotic aortic aneurysm. Eur J Vasc Endovasc Surg. 2017:54:464-71.

35. Araoka H, Baba M, Kimura M, Abe M, Inagawa H, Yoneyama A. Clinical characteristics of bacteremia caused by Helicobacter cinaedi and time required for blood cultures to become positive. J Clin Microbiol. 2014;52: 1519-22.

36. Miyake N, Chong Y, Nishida R, Nagasaki Y, Kibe Y, Kiyosuke M, et al. A dramatic increase in the positive blood culture rates of Helicobacter cinaedi: the evidence of differential detection abilities between the Bactec and BacT/Alert systems. Diagn Microbiol Infect Dis. 2015;83:232-3.

37. Doern CD, Mirrett S, Halstead D, Abid J, Okada P, Reller LB. Controlled clinical comparison of new pediatric medium with adsorbent polymeric beads (PF plus) versus charcoal-containing PF medium in the BacT/Alert blood culture system. J Clin Microbiol. 2014;52:1898-900.

38. Kirn TJ, Mirrett S, Reller LB, Weinstein MP. Controlled clinical comparison of BacT/Alert FA plus and FN plus blood culture media with BacT/Alert FA and FN blood culture media. J Clin Microbiol. 2014;52:839-43.

\section{Publisher's Note}

Springer Nature remains neutral with regard to jurisdictional claims in published maps and institutional affiliations.

Ready to submit your research? Choose BMC and benefit from:

- fast, convenient online submission

- thorough peer review by experienced researchers in your field

- rapid publication on acceptance

- support for research data, including large and complex data types

- gold Open Access which fosters wider collaboration and increased citations

- maximum visibility for your research: over $100 \mathrm{M}$ website views per year

At $\mathrm{BMC}$, research is always in progress.

Learn more biomedcentral.com/submissions 